\title{
ANALYSIS ON TRAMMEL NET AND PA MONOFILAMENT SHRIMP NET TOWARDS SHRIMP FISHING IN KAIMANA BAY, INDONESIA
}

\author{
Ulath M. Ali, Handayani, Razak Abu Darda, Sururi Misbah, Gunaisah Endang, \\ Sudirman, Sepri, Suruwaky Amir, Muhfizar, Mustasim* \\ Politeknik Kelautan and Perikanan Sorong, Indonesia
}

\author{
Simau Silvester \\ Politeknik Kelautan and Perikanan Bitung, Indonesia \\ *E-mail: mustasim@kkp.go.id
}

\begin{abstract}
Kaimana waters is an area in West Papua, Indonesia potential for shrimp fishing; the fishermen use trammel net and PA monofilament shrimp nets. The data analysis consisted of analyses towards effectiveness, efficiency and low impact measurement of the catch. The findings showed that trammel nets were more effective and efficient in shrimp fishing than PA Monofilament shrimp nets; however, based on the by-catch both equipment caught equal number of shrimps.
\end{abstract}

\section{KEY WORDS}

Effectiveness, efficiency, low impact, shrimp fishing, Kaimana Bay.

Shrimp trawlers in the Arafura Sea have been developed since 1969. Shrimp trawling areas include Sele Strait, Bintuni Bay, Fak Fak, Kaimana, Dolak and Aru Island of which coordinates are $130^{\circ}$ East Longitude except the coastal waters of each of the islands limited by a 10 meter isobaths (Article 1). The permission for shrimp trawling in Arafura Sea which began in 1982 has resulted in an increase in exploitation of natural resources. Suman and Satria (2014); Purwanto \& Nugroho (2010) stated that shrimp fishing or trawling in Arafura Sea can now be categorized as over-exploitation. It happened because fishermen used shrimp trawl as their fishing equipment and consequently, the amount of by-catch is pretty high and the environment is damaged ((Thomas, Sreedevi and Kurup, 2006; Brennan et al., 2016; Thomas et al., 2017). Current potential of shrimps is 49,500 tons/year with total allowable catch of around 39,600 tons/year. Due to the overexploitation, the number of shrimp trawlers has to be reduced to 225 units. Otherwise, environmental sustainability can be severely damaged and the number of shrimps will decline sharply.

The government has issued several regulations in order to maintain shrimp fishing in Arafura Sea, for example: Presidential Decree No. 39/1980; Ministry of Agriculture Decree No. 930/Kpts/Um/12/1982; Directorate General of Fisheries Decree No. IK. 010/S3.8075/82K; Directorate General of Fisheries Decree No. IK.010/S3.8063/82K; 1982 Presidential Decree number 85; Ministry of Agriculture Decree No. 816/Kpts/lk.120/11/90; the 2004 Decree number 3 and 13; Ministry of Fisheries and Marine Affairs Decree No. PER.05/MEN/2008 Article 74; Directorate General of Capture Fisheries Decree No. 08/DJPT/2010 revised into Directorate General of Capture Fisheries Decree No. 38/DJPT-2010. These nine regulations were unable to maintain or supervise shrimp fishing in the area and consequently have failed to overcome shrimp fishing crisis. In addition, the government has issued the Ministry of Fisheries and Marine Science regulation number 2/ Permen- KP/ 2015 that prohibited Trawl and Seine Nets as fishing equipment. Pukat Hela and Pukat Tarik, two types of trawl has declined number of fish quite sharply and damaged marine ecosystem including fish. Therefore, the fishing equipments are prohibited in Indonesia including Arafura Sea. Kurniawan et.al (2017) explained that banning pukat hela for shrimp fishing will increase number of unused resources and lead to scarcity of shrimp catches. 
Kaimana water is a suitable area for shrimp fishing in West Papua. This area is famous for penaeid shrimp fishing in which shrimp fishing is conducted between 5 and 35 meter deep. The watershed consists of sandy mud and color of the waters is close to gray. Mangrove forest and both small and large estuary can be found along the coast (Astuti, 2005). Both traditional fishermen and shrimp industry carry out their operation in this water. The traditional fishermen use trammel net, PA monofilament shrimp nets and other fishing equipment. Due to the Ministry of Fisheries and Marine Affairs, which prohibits certain fishing equipment that may damage the environment, fishermen should find low impact and efficient fishing equipment. Objective of this study is to analyze effectiveness, efficiency and low impact of trammel net and PA Monofilament shrimp nets towards the traditional fishermen's shrimp fishing in Kaimana water.

\section{MATERIALS AND METHODS OF RESEARCH}

The study used survey technique. The setting is Kaimana Bay and Arguni Bay, located in Kaimana Municipality, West Papua (See Figure 1 for the location). The population was 47 fishermen who used trammel net and 73 fishermen who used PA monofilament shrimp nets. The sampling technique was stratified random sampling.

The equipment and materials used were trammel net, monofilament shrimp fishing nets, digital camera, measuring board, GPS, digital scale, water quality measuring unit (Digital Aquared), stationery and questionnaires.

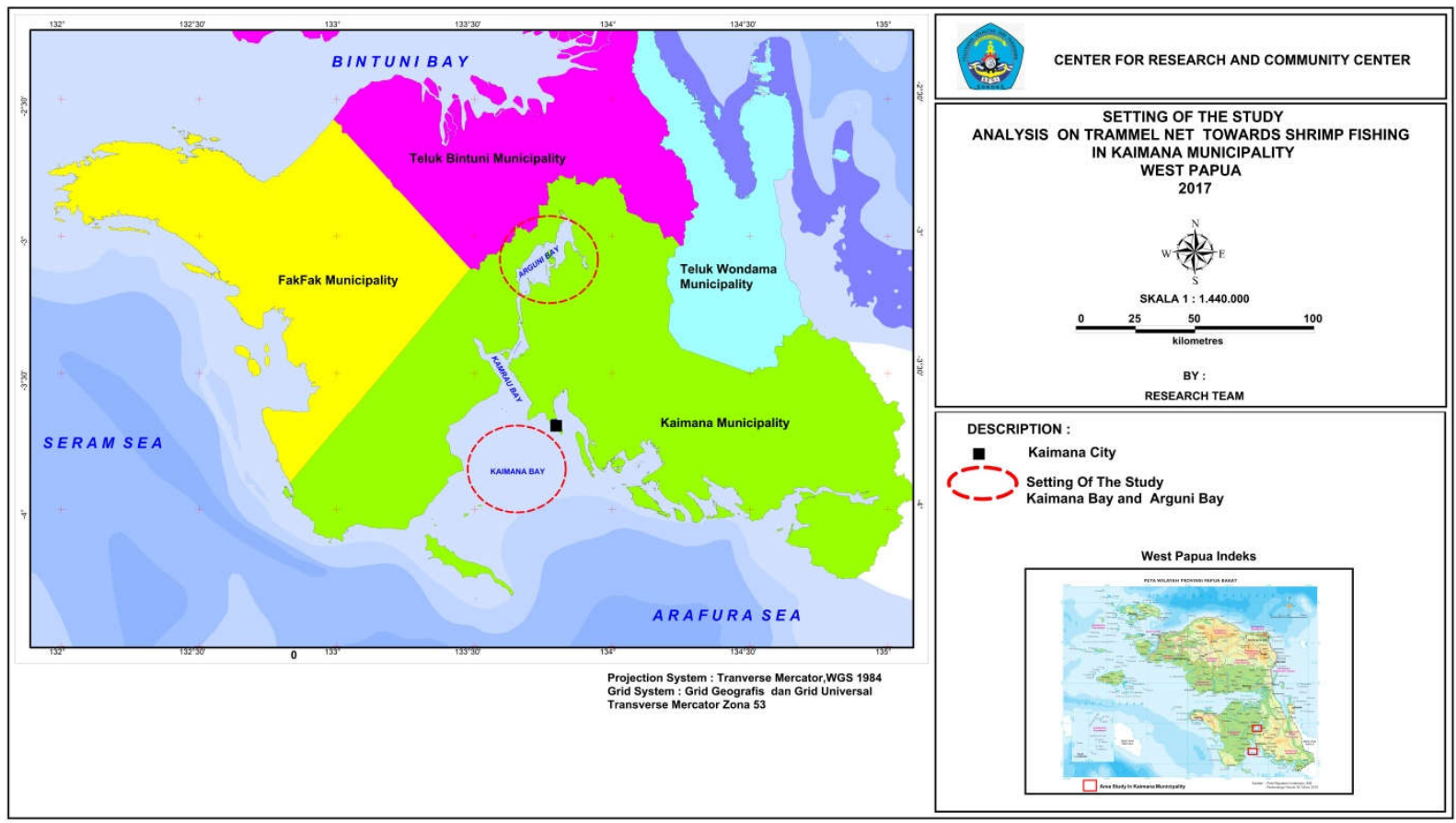

Figure 1 - Setting of the Study

The study was divided into two stages, primary data collection and secondary data collection. Primary data collection was conducted between September and November 2017, in Kaimana Bay and Arguni Bay, Kaimana Municipality, West Papua, while secondary data collection was conducted between July and November, 2017 in Kaimana Municipality, West Papua. Primary and secondary were obtained using observation, interviews and questionnaires. The primary data, obtained in the area where trammel net and monofilament shrimp fishing net were used, consisted of: characteristics of shrimp fishing unit operated, aquatic environment, main catch and by-catch and operating costs, while the secondary data were taken from certain documents available at the relevant agencies.

Effectiveness was analyzed with the following formula: 


$$
\text { Effectiveness }=\frac{\text { Actual Output }}{\text { Targeted Output }}
$$

Criteria: $E \geq 1$ means effective and $E<1$ means not effective.

Impact of Fishing Equipments, represented by by-catch, was estimated using the following formula:

$$
\text { By-Catch Percentage }=\frac{\text { Bycatch }}{\text { Main Catch }} \times 100 \%
$$
impact.

Criteria: $\mathrm{Pbc}<20 \%$, low impact; $20 \%<\mathrm{Pbc}<50 \%$, middle impact; $\mathrm{Pbc}>50 \%$, high

Efficiency was measured with the following formula:

$$
\text { Efficiency }=\frac{\text { Output }}{\text { input }} \times 100 \%
$$

Where: Output $=$ Total catch $\mathrm{x}$ sales price; Input $=$ Total operating cost.

Criteria: $<100 \%=$ not efficient; $101,1 \%-150 \%=$ fair; $>151 \%=$ efficient.

To find out which fishing equipment has the best performance, the researchers conducted normality test is followed by t-test and f-test with confidence interval of $95 \%$ using Minitab software.

\section{RESULTS AND DISCUSSION}

Effectiveness of Trammel Net and PA Monofilament Shrimp Nets. Hidayat (1986) stated that effectiveness refers to how far target (quantity, quality and time) has been achieved and Jhon (1986) postulated that effectiveness is achieving target output by comparing estimated output and real output. When OA> OS, it is categorized as effective.

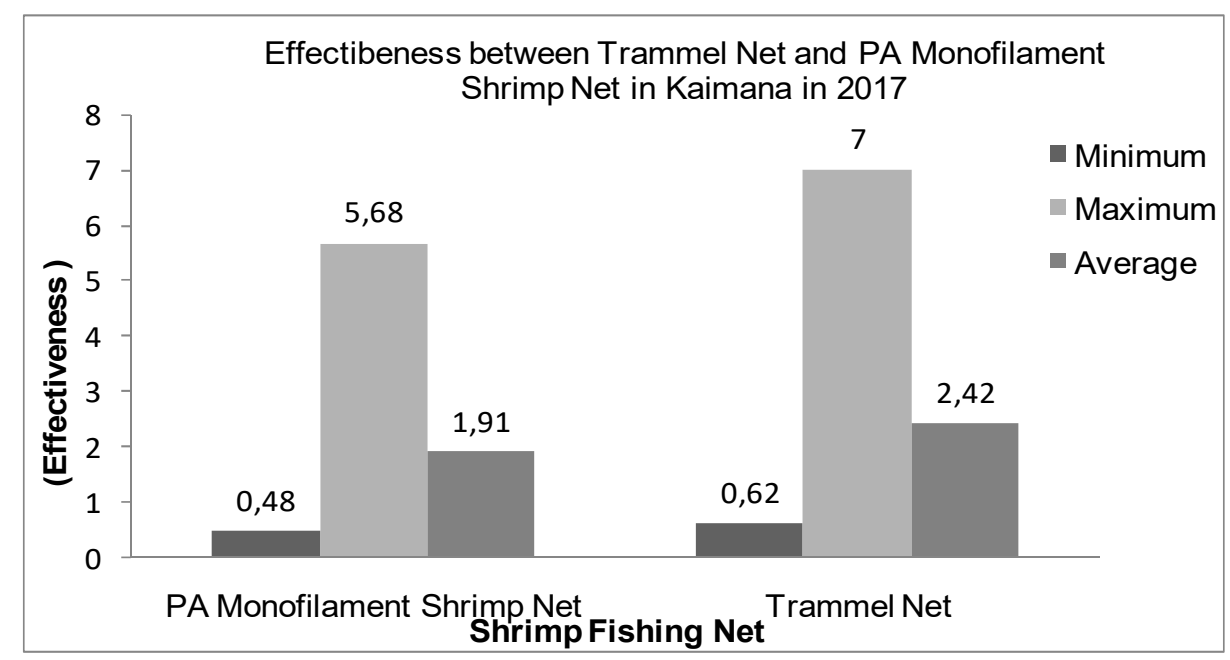

Figure 2 - Effectiveness between shrimp fishing with trammel net and shrimp fishing with monofilament fish net

Effectiveness of shrimp fishing using trammel net and PA monofilament shrimp net was measured by comparing between actual catch for each fishing equipment and a minimum estimated catch (target). This target should be in accordance to production cost and minimum estimated profit. Based on the interview, estimated catch in one shrimp fishing trip was $8 \mathrm{kgs}$. Figure 2 showed effectiveness of shrimp fishing using the PA monofilament fishing net and trammel net where there were 47 samples of fishing trips using the PA monofilament fishing net and 62 samples of fishing trip using trammel net. 
Figure 2 showed that both fishing equipments had different contribution towards shrimp fishing (catch). Both equipment is effective for shrimp fishing because their scores are higher than 1. Trammel net had higher effectiveness with the highest score of 7 and average score of 2.42, compared to the monofilament shrimp nets of which highest score was 5.68 and average score was 1.91. However, there were several non-effective samples $(0.48$ in the monofilament shrimp net and 0.62 in the trammel net) or 12 samples $(26 \%)$ for the monofilament shrimp net and $8(13 \%)$ for the trammel net. These 20 samples were noneffective because they were not able to meet the targeted catch. It was difficult to foresee what would take place in every shrimp fishing trip and therefore, fishermen were unable to guarantee that they would meet targeted amount of catch in every trip. Nevertheless, using the 20 samples, fishermen were able to cover their operating cost and as the result, kept using the fishing equipments while hoping to catch more shrimps.

The Kolmogorov Smirnov test that measured effectiveness of both fishing equipment showed that the data were distributed normally and therefore, the researchers proceeded to conducting F-test or t-test.

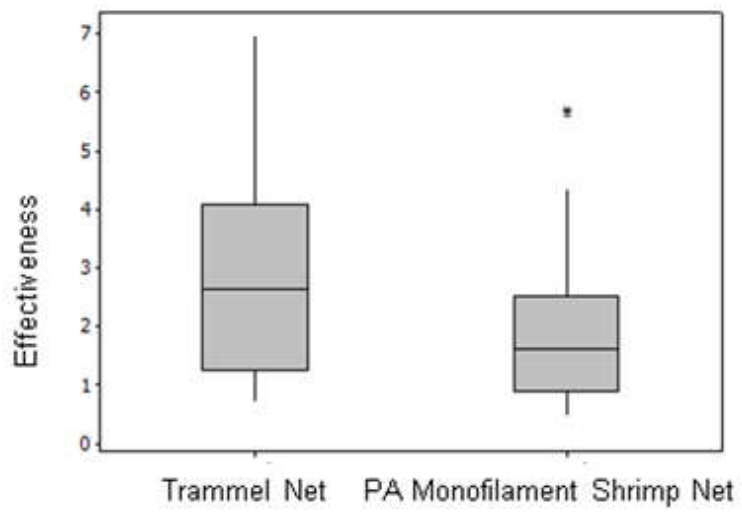

Figure 3 - Effectiveness of Both Fishing Equipments

Based on $F$-test, $F_{\text {value }}(F=2.12)>F_{\text {tab }}\left(F_{(0.05 ; 64 ; 64)}=1.63\right)$ and thus, it can be concluded that both fishing equipment had quite a significant difference in terms of effectiveness. In general, trammel net was more effective than monofilament shrimp nets. Furthermore, $t$-test showed that $t_{\text {value }}\left(t_{\text {value }}=3.1\right)>t_{\text {tab }}\left(t_{(0.05 ; 64)}=1.99\right)$ which means that both fishing equipment had quite a significant difference in terms of effectiveness; in general, trammel net was more effective than monofilament shrimp nets.

Effectiveness scores will change in accordance to shrimp fishing season. It will change based on how many shrimps fishermen caught (catch). Figure 4 described effectiveness of the fishing equipment during east monsoon and west monsoon.
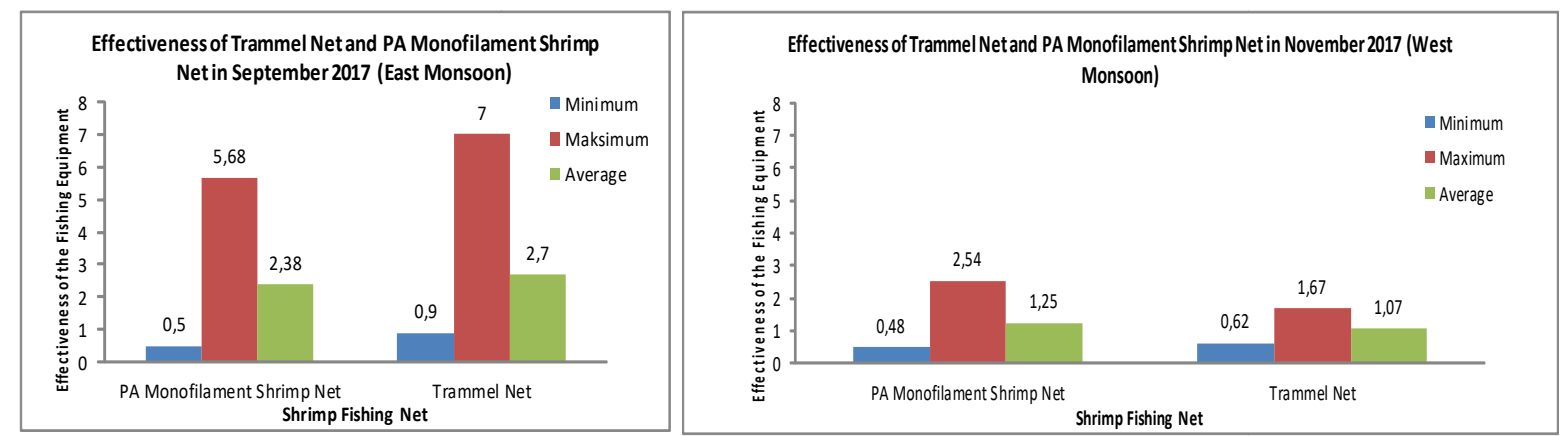

Figure 4 - Effectiveness Score in East Monsoon and West Monsoon

Figure 4 showed that the trammel net was more effective during East Monsoon (higher maximum score and average score). At the opposite, the monofilament shrimp nets were 
more effectiveness than the trammel net during West Monsoon. During West Monsoon, Kaimana Bay is pretty calm and as the consequence, it is easier to catch shrimps with the monofilament shrimp nets located in the coastal area and estuary compared to doing so with the trammel net. Besides that, shrimp migration and shrimp fishing season in Arguni Bay and nearby water take place during the West Monsoon.

Efficiency of Trammel Net and PA Monofilament Shrimp Nets. Besides the trammel net and the monofilament shrimp nets, the fishermen in Kaimana used long boat for fishing. Their activity is categorized as small-scale fishing as they are using limited fishing equipment and fishing in the coastal area only. As the result, in this context, efficiency refers to comparison between sales price and total operating cost. Figure 5 showed efficiency score of both fishing equipment.

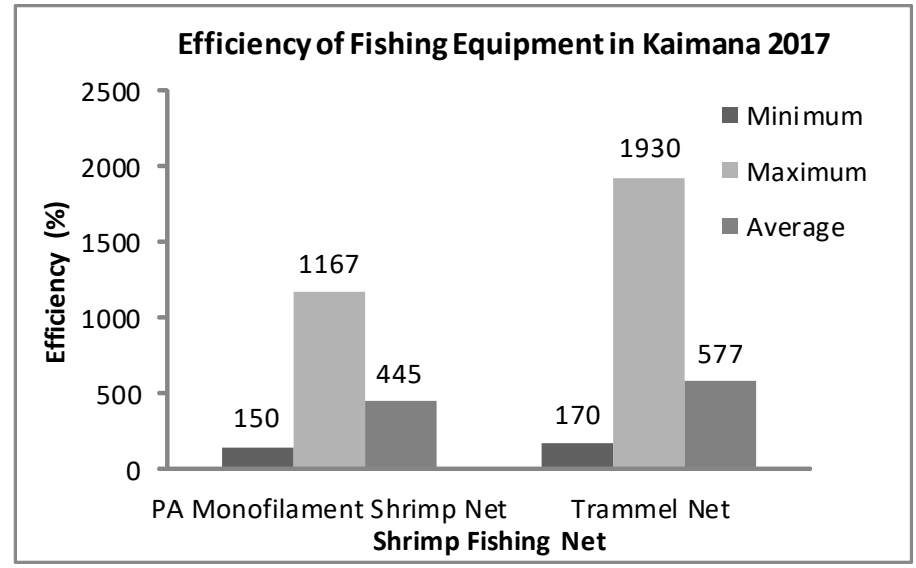

Figure 5 - Efficiency of Monofilament Shrimp Nets and Trammel Net

Based on Figure 5, average efficiency of trammel net was $577 \%$ and that of monofilament shrimp nets was $445 \%$. In general, the trammel net had higher efficiency compared to the monofilament nets. It happened because 1) sales price of the shrimps caught using trammel net was higher than that caught using the monofilament shrimp nets (50,000 rupiahs $/ \mathrm{kg}$ for trammel net and 45,000 rupiahs $/ \mathrm{kg}$ for the monofilament net), and 2) the monofilament nets resulted in higher operating cost than the trammel net. The Kolmogorov Smirnov test that measured effectiveness of both fishing equipment showed that the data had normal distribution and therefore, the researchers proceeded to conducting parametric test (F-test or t-test).

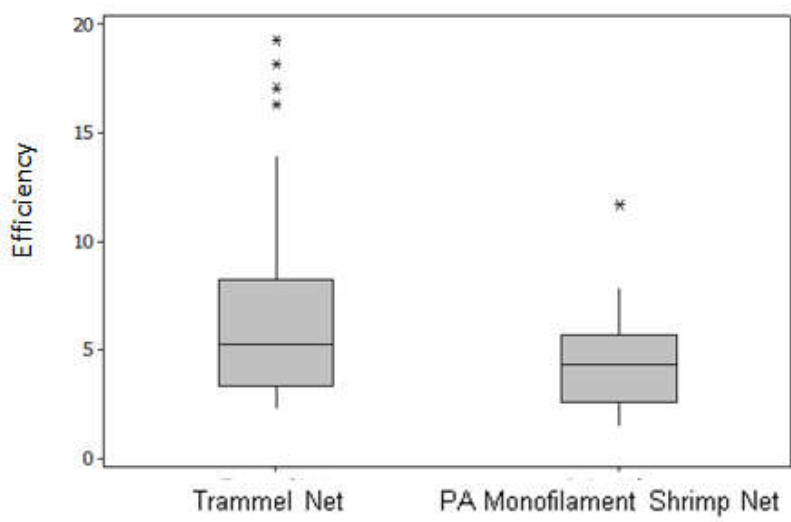

Figure 6 - Efficiency Scores between Trammel Net and Monofilament Shrimp Nets

Based on the analysis, $F_{\text {value }}\left(F_{\text {value }}=4.36\right)>F_{\text {tab }}\left(F_{(0.05 ; 64 ; 64)}=1.63\right)$ and $t_{\text {value }}\left(t_{\text {value }}=\right.$ 2.98) $>t_{\text {tab }}\left(t_{(0.05 ; 64)}=1.99\right)$. Therefore, both fishing equipment had quite a significant difference in terms of efficiency and trammel net was more efficient compared to the 
monofilament nets. PA monofilament shrimp nets required higher operating cost. Furthermore, the shrimps were sold in Kaimana (city) and thus, the fishermen who used the monofilament net had to transport their catch from Arguni to Kaimana. These fishermen rented a public transportation from Tanggaromi to Kaimana for 300,000 rupiahs. 3-5 fishermen rented one means of public transportation. Besides selling their catch, the Arguni fishermen went to Kaimana (city) to shop for grocery and ice blocks for their following fishing trip.

Efficiency also depends upon fishing season. East monsoon is the most suitable season for shrimp fishing using trammel net in Kaimana, and at the opposite, West monsoon is the most suitable one for shrimp fishing using monofilament shrimp nets for Arguni fishermen. As the result, efficiency score for each fishing season changed. Figure 5 described efficiency of both fishing equipment during east monsoon and west monsoon.
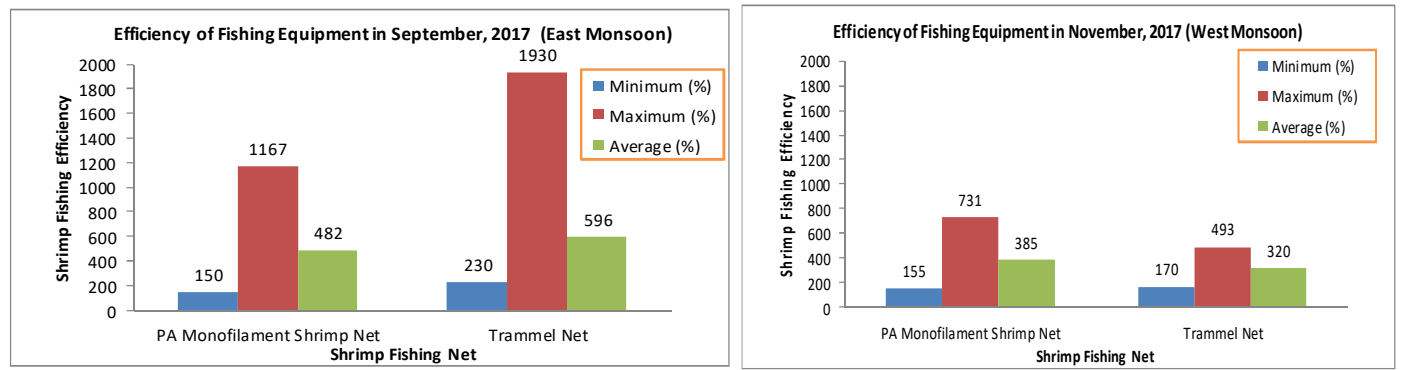

Figure 7 - Efficiency Score between Monofilament Nets and Trammel Nets in East and West Monsoon

Figure 7 showed that the trammel net was more efficient during East Monsoon than the monofilament shrimp nets. At the opposite, the monofilament shrimp nets were more efficient than the trammel net during West Monsoon. During West Monsoon, Arguni fishermen, who went shrimp fishing using monofilament nets, caught more shrimps than Kaimana fishermen who used the trammel net and therefore, their output or sales price is higher while the operating cost remained stable.

Low Impact by-Cath of Trammel Net and PA Monofilament Shrimp Nets. By-catch refers to another fish or marine biota getting caught besides a targeted catch (Mardjudo, 2011). By-catch of the trammel net and the monofilament shrimp nets refers to all marine biota getting caught besides shrimps. Most of the by-catch is fish and crabs. Even though the fishermen can sell or consume the by-catch, they found it disturbing because releasing the fish and crabs back to the sea was time consuming and by-catch can damage the nets. Figure 8 showed by-catch analysis in the shrimp fishing.

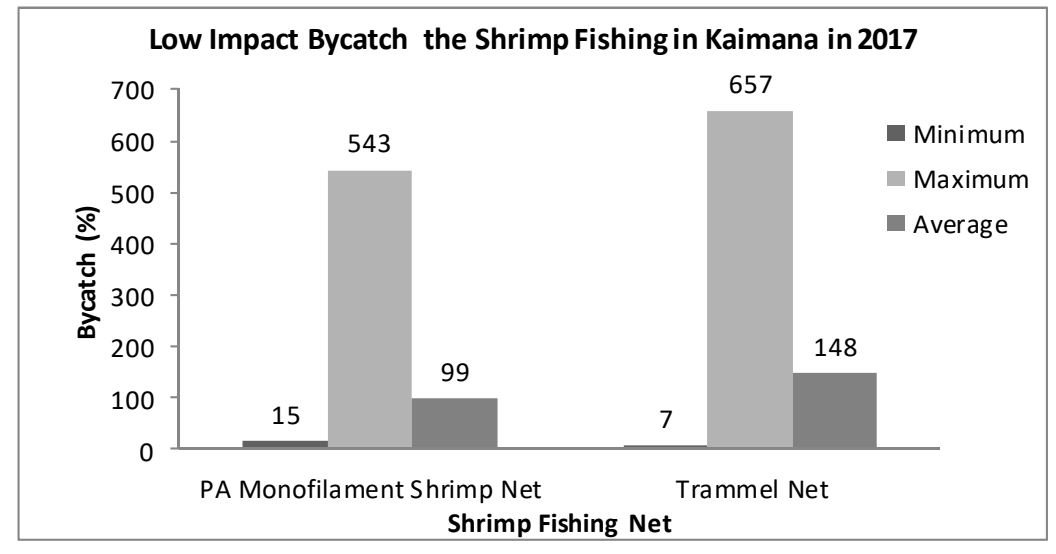

Figure 8 - By-catch in Shrimp Fishing using Monofilament Shrimp Nets and Trammel Net

In general, both fishing equipment had high percentage of by-catch (> 50\%) and thus, was categorized as high impact. Trammel net had higher percentage of by-catch than 
monofilament shrimp nets. It happened because trammel net consisted of three layers and fish got stuck more easily. Based on the interview, by-catch percentage depends heavily upon fishing season. During shrimp fish season, when number of shrimps is abundant, bycatch percentage is decreasing and at the opposite, when shrimps are scarce, by-catch percentage is increasing.
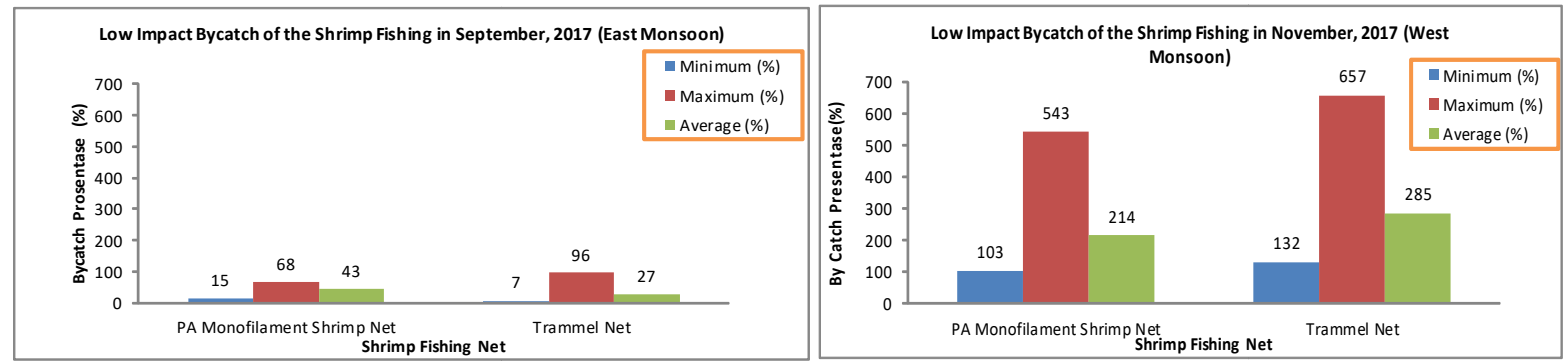

Figure 9 - By-catch Comparison between East Monsoon and West Monsoon

Figure 9 explained that in East Monsoon (shrimp fishing season), by-catch percentage was declining (middle impact) but in West Monsoon, by-catch percentage was increasing very sharply. It was predicted that shrimp density, more particularly adult shrimp, disturbed some fish. Shrimp head and tail are sharp and as the result, fish swims to other places to avoid the shrimp. The Kolmogorov Smirnov test that measured by-impact percentage of both fishing equipment showed that the data had normal distribution and therefore, the researchers proceeded to conducting parametric test (F-test or t-test).

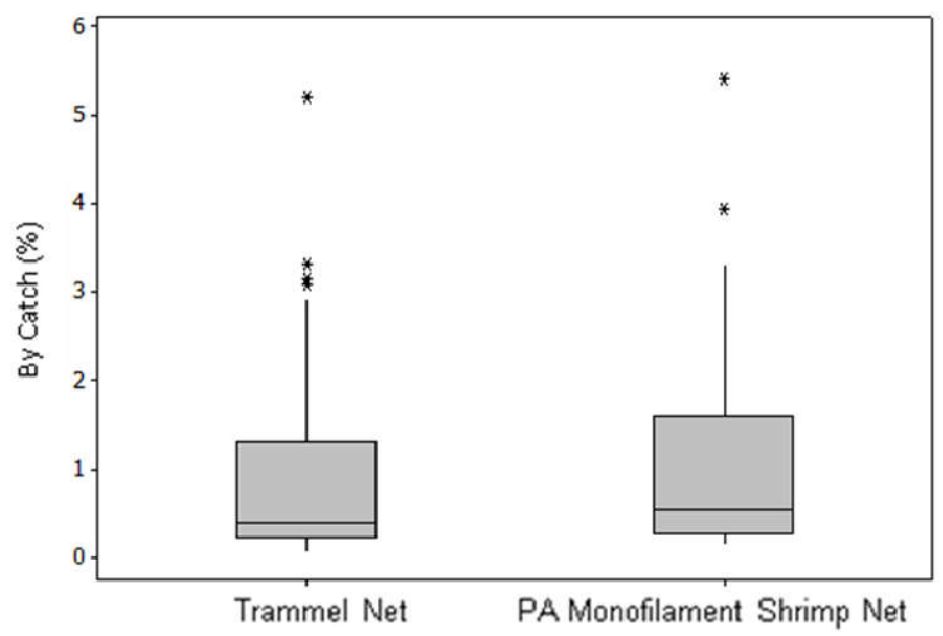

Figure 10 - By-catch between Trammel Net and Monofilament Shrimp Nets

$F_{\text {test }}$ showed that $F_{\text {value }}\left(F_{\text {value }}=1.02\right)<F_{\text {tab }}\left(F_{(0.05 ; 64 ; 64)}=1.63\right)$ and $t_{\text {value }}\left(t_{\text {value }}=-0.57\right)<$ $t_{\text {tab }}\left(t_{(0.05 ; 64)}=1.99\right)$. In conclusion, the percentage of by-catch between those fishing equipment difference was the same (no significant difference). Trammel net caught as many bycatch as monofilament net. Negative (-) $t_{\text {value }}$ showed that by-catch percentage of the trammel net was slightly lower than that of the monofilament shrimp nets.

\section{CONCLUSION}

The findings showed that trammel net has higher effectiveness and efficiency score compared to PA monofilament shrimp nets. However, by-catch percentage of both equipments is quite similar. Therefore, even though trammel net is a better alternative for shrimp fishing, further analysis to re-design the trammel net is required in order to decrease by-cath percentage. 


\section{ACKNOWLEDGMENTS}

The authors would like to thank all fishermen participating in this study. The authors would also like to send their gratitude to the staffs of the Department of Fisheries and Marine Affairs of Kaimana and fishing instructors in Kaimana.

\section{REFERENCES}

1. Astuti, E, M,. 2005. Dimensi Unit Penangkapan Pukat Uandg and tingkat Pemanfaatan Sumberdaya uandg di Perairan Laut Arafura (Bachelor Thesis). Bogor: IPB.

2. Brennan, M. L., Davis, D., Ballard, R. D., Trembanis, A. C., Vaughn, J. I., Krumholz, J. S., \& Duman, M. (2016). Quantification of bottom trawl fishing damage to ancient shipwreck sites. Marine Geology, 371, 82-88.

3. Hidayat, 1986. Teori Keefektifas dalam Kinerja Karyawan. Gajah Mada University Press; Yogyakarta.

4. Kurniawan, W., Riyanto, A., and Amani Edi Santoso., 2017. Uji operasional alat tangkap ramah lingkungan jaring ciker (jaring tiga lapis atau trammel net). Buletin Teknik Litkayasa, BTL Vol. 15 No. 1 June 2017., pp.47-55.

5. Purwanto \& D, Nugroho,. 2010. Tingkat Optimal Pemanfaatan Stok Uandg, ikan de,ersal and pelagis kecil di Laut Arafuru. Jurnal Penelitian Perikanan. P4KSI, Vol. 16 (4): 311 312.

6. Suman, A \& F. Satria. 2014. Opsi pengelolaan sumberdaya udang di laut arafura (wpp 718). J. Kebijak.Perikan.Ind. Vol.6 No.2: 97-104.

7. Schemerhorn, Jr \& Jhon, R,. 1986. Management for Productivity. New York; Jhon Wiley \& Son.

8. Thomas, J. V., Sreedevi, C. and Kurup, B. M. (2006) 'Variations on the infaunal polychaetes due to bottom trawling along the inshore waters of Kerala (south-west coast of India)', Indian Journal of Marine Sciences, 35(3), pp. 249-256.

9. Thomas, L., Venu, S., Malakar, B., Nagesh, R., \& Basumatary, G. (2017). An assessment on the impact of bottom trawling to the demersal fisheries and benthic diversity of Andaman Islands, India. Regional Studies in Marine Science, 10, 20-26. 